


\title{
Unconstitutionality of criminal liability for filing inaccurate information in Ukraine: critical legal analyses
}

\author{
DOI: https://doi.org/10.46398/cuestpol.3969.07
}

\author{
Andrii Vozniuk * \\ Dmitriy Kamensky ** \\ Olexandr Dudorov *** \\ Roman Movchan **** \\ Andriy Andrushko *****
}

\begin{abstract}
The investigation reveals shortcomings in the arguments of the Constitutional Court of Ukraine on the recognition of article 366-1 of the Criminal Code as not being in conformity with the Constitution, in terms of:(a) the court's lack of authority to criminalize socially dangerous acts; (b) lack of argumentation on the absence of social harm in the non-submission of a declaration and in the presentation of inaccurate information; (c) positive foreign experience; (d) conformity of article 366-1 of the Criminal Code of Ukraine with the principle of the rule of law. The article employs a set of legal research methods, including terminological, systemic-structural, formallogical, and comparative-legal. It is stressed that:(a) the criminalization of a socially harmful act is a matter for the legislator, not the Constitutional Court of Ukraine, to decide; (b) the decision does not present or refute any argument on the element of social harmfulness relating to the nonsubmission of a declaration and the declaration of inaccurate information. On the basis of the investigation, it has been concluded that the decision of the Constitutional Court on the recognition of article 366-1 of the Criminal Code does not comply with the Constitution and has not been sufficiently
\end{abstract} substantiated.

* $\quad$ Doctor of Legal Sciences, Head of Research Laboratory at the National Academy of Internal Affairs. ORCID ID: http://orcid.org/oooo-0002-3352-5626. Email: vaa.999999@gmail.com

** Doctor of Legal Sciences, Head of Legal Courses Department at Berdyansk State Pedagogical University. ORCID ID: https://orcid.org/oooo-0oo2-3610-2514. Email: dm.kamensky@gmail.com

*** Doctor of Legal Sciences, Head of Research Laboratory at Luhansk State University of Internal Affairs named after E.O. Didorenko. ORCID ID: https://orcid.org/oooo-0003-4860-0681. Email: o.o.dudorov@gmail.com

**** Doctor of Legal Sciences, Associate Professor of the Department of Constitutional, International and Criminal law at Donetsk National University named after Vasyl Stus. ORCID ID: https://orcid. org/oooo-0003-2074-8895. Email: romanmov1984@gmail.com

$5{ }^{* * * * *} \mathrm{PhD}$, Associate Professor of the Department of Criminal Law and Process at Uzhhorod National University. ORCID ID: https://orcid.org/oooo-0002-7735-7898. Email: andrushko525@gmail.com 
Andrii Vozniuk, Dmitriy Kamensky, Olexandr Dudorov, Roman Movchan y Andriy Andrushko

Keywords: declaration of unreliable information; public corruption; corruption-related criminal offense; unconstitutionality of the law; rule of law.

\section{Inconstitucionalidad de la responsabilidad penal por presentar información inexacta en ucrania: análisis legales críticos}

\section{Resumen}

La investigación revela deficiencias de los argumentos del Tribunal Constitucional de Ucrania sobre el reconocimiento del art. 366-1 del Código Penal como el hecho que no se ajusta a la Constitución, en términos de: a) falta de autoridad de este Tribunal para tipificar como delito actos socialmente peligrosos; b) falta de argumentación sobre la ausencia de perjuicio social en la no presentación de declaración y en la presentación de información inexacta; c) experiencia extranjera positiva; d) conformidad del art. 3661 del Código Penal de Ucrania con el principio del estado de derecho. El artículo emplea un conjunto de métodos de investigación jurídica, entre los que se encuentran terminológicos, sistémicos-estructurales, formaleslógicos y comparativos-legales. Se destaca que: a) la criminalización de un acto socialmente dañino es un asunto que debe decidir el legislador, no el Tribunal Constitucional de Ucrania; b) la decisión no presenta ni refuta ningún argumento sobre el elemento de lesividad social relacionado con la no presentación de declaración y la declaración de información inexacta. Sobre la base de la investigación, se ha concluido que la decisión del Tribunal Constitucional sobre el reconocimiento del art. 366-1 del Código Penal no cumple con la Constitución y no se ha fundamentado suficientemente.

Palabras clave: declaración de información no confiable; corrupción pública; delito relacionado con la corrupción; inconstitucionalidad de la ley; Imperio de la ley.

\section{Introduction}

Corruption remains among the major threats to Ukraine. In terms of the nature of its danger, it can be compared to the war in Eastern Ukraine. While penetrating into all spheres of public life, it damages the most important social values of both state as a whole and its individual citizens. In particular, it negatively effects market economy relations, such as stock market and institutional investors (Kamensky et al., 2020). Therefore, the 
fight against corruption remains priority for both public authorities and members of civil society. In view of this, practices aimed at preventing and stopping any corruption offenses are being implemented in Ukraine. They include, in particular, creation of the mechanism for mandatory declaration of existing assets by persons covered by the Law of Ukraine "On Prevention of Corruption" (2014).

When talking about corruption on the specific national level, it should be also noted that critical study of relevant foreign experience in this area will facilitate transposition of relevant provisions of criminal law of various foreign countries in order to adapt, converge, harmonize, unify, etc. (Vozniuk et al., 2020). Indeed, any given state should not be left legally isolated when searching for the appropriate solutions and remedies to fight corruption related offenses.

Criminal law provision previously included in Art. 366-1 of the Criminal code of Ukraine (2001), which established the grounds of criminal liability for declaring unreliable information, has been a vital component of the mechanism of electronic declaration in Ukraine. This norm has been rightly recognized as an important tool to deter persons authorized to perform functions of state or local self-government from committing corruption offenses (Cherniavskyi and Vozniuk, 2019).

However, a powerful strike was made against anti-corruption mechanism in Ukraine on October 27, 2020, when the Constitutional Court of Ukraine (hereinafter - CCU) issued a ruling, which has partially "paralyzed" the work of the National Agency for Prevention of Corruption and "destroyed" some of electronic declaration tools. The CCU ruling provided for the recognition of Art. 366-1 of the Criminal Code of Ukraine (Decision of the CCU, 2020) as the provision, which does not correspond to the Constitution. Such actions of the exclusive body of constitutional jurisdiction in Ukraine have been ambiguously perceived by members of civil society: some have supported the decision, while others have labeled it as the one with significant shortcomings. Therefore, it is important to thoroughly analyze Court arguments for striking down Art. 366-1 of the Criminal Code of Ukraine (2001) as unconstitutional.

\section{Methodology}

The article uses a set of research methods, namely: terminological, system-structural, formal-logical, comparative-legal. Theoretical basis of the study is constituted by the works of scientists, some opinions of CCU judges, provisions of the Criminal Code of Ukraine (2001) and the Law of Ukraine "On Prevention of Corruption" (2014), as well as their application practice. 
The structural method has been employed to describe construction of the Criminal Code provisions related to liability for filing inaccurate information by public officials.

Also, using systemic method has allowed characterizing current limits of permissible behavior in the area of public service in their relationship with the norms of other legal bodies, including constitutional law.

Finally, the formal-legal method enabled the authors to analyze legal substance of the national Criminal Code provisions aimed at fighting corruption related offenses in general and filing inaccurate information in particular.

\section{Recent research and findings}

While ruling on the unconstitutionality of Art. 366-1 of the Criminal Code of Ukraine (2001), the CCU relied on two arguments:

1) non-compliance with the principles of justice and proportionality as elements of the rule of law principle primarily due to non-compliance with the criteria of criminalization of specific behavior as described in Art. 366-1 of the Criminal Code of Ukraine (2001);

2) violation of the rule of law principle, in particular elements of legal certainty and predictability of the law.

The first argument of unconstitutionality is based on non-compliance with the principles of justice and proportionality as elements of the rule of law principle, primarily due to non-compliance with the criteria of criminalization of the act described in Art. 366-1 of the Criminal Code of Ukraine (2001). "By their legal nature, such acts are not capable of causing significant harm to a natural or legal person, society, or state to the extent necessary to label them as socially dangerous ..." (Decision of the CCU, 2020).

The establishment of criminal liability for such acts is an excessive punishment for committing such offenses. Negative consequences of a person prosecuted for committing crimes under Article 366-1 of the Criminal Code of Ukraine (2001) are disproportionate to the damage, which has occurred or may have occurred in the event of such acts commission (Decision of the CCU, 2020).

Of course, such opinion has its merits, and if it is embodied in the relevant decision by the judges of the constitutional review body, it becomes a requirement, which, from a legal point of view, is subject to mandatory implementation. At the same time, position of the CCU is not indisputable, and therefore counter-arguments can be provided to refute it. 
First, criminalization of a socially harmful act is a matter for the legislator, not for the CCU, to decide.

Only the Parliament should determine an act as socially harmful, and therefore it decides which type of behavior should be recognized as a criminal offense, and which should not. This position was supported by the Presidents of GRECO and the Venice Commission (National Agency of Corruption Prevention, 2020), as well as by the CCU judge O. Pervomaisky (Pervomaisky, 2020).

Second, the decision does not present or refute any argument about the social harmfulness element related to not submitting declaration and declaring inaccurate information.

The CCU did not even make an effort to establish, what the public danger of this crime was, but limited itself to stating inconsistencies. This is a purely subjective opinion by some judges of the CCU. It is no coincidence that representatives of this body, such as S. Holovaty (Holovaty, 2020), V. Lemak (Lemak, 2020), (Voznyuk, 2019) V. Kolisnyk (Kolisnyk, 2020) and O. Pervomaisky (Pervomaisky, 2020) view the ruling as unfounded.

\section{Results of the study}

Criminalization of the act outlined in Art. 366-1 of the Criminal Code of Ukraine (2001), was necessary to ensure a mechanism for combating corruption offenses, the level, structure and dynamics of which remain of serious concern in Ukraine. Statistics demonstrate a significant number of recorded facts of crimes under Art. 366-1 of the Criminal Code of Ukraine (2001): in 2015, 25 of such criminal offenses were registered, in $2016-58$, in $2017-1134$, in $2018-1541$, in $2019-1118$, for 9 months of $2020-861$ (Statistical reporting, 2016-2020).

Social conditionality of the establishment of relevant criminal law prohibitions (submission of knowingly inaccurate information in the declaration and intentional failure to submit declaration) is determined by the following circumstances.

1. Social harmfulness of such acts. Social harmfulness of corruption offenses has been repeatedly confirmed by academics (Dudorov et al., 2019; Cherniavskyi and Vozniuk, 2019; Nathanson, 2013). The CCU ruling has identified corruption among the major threats to the national security of Ukraine (Decision of the CCU, 2020).

Social harmfulness of the intentional failure to file a declaration means that such act: 1) creates conditions for the concealment of property owned, used or disposed of by the declarant, his other assets, expenses, financial 
Andrii Vozniuk, Dmitriy Kamensky, Olexandr Dudorov, Roman Movchan y Andriy Andrushko

obligations, etc.; 2) complicates detection of corruption or other offenses; 3) prevents effective pre-trial investigation of illicit enrichment; 4) does not provide the opportunity to properly control observance of the principles of ethics, first of all requirements of integrity, by the persons authorized to perform state or local government functions.

Social harmfulness of filing knowingly inaccurate information in the declaration by the designated person means that such act: 1) serves as one of the means to conceal corruption- related or other illegal activities, helps such persons to avoid responsibility by for their wrongdoing; 2) encroaches on the constitutional right of citizens to vote (due to false information, citizens may be misled during election to public authorities and local governments); 3) violates requirements of transparency to candidates during competition procedure for their appointment to a certain position, and therefore there is a threat of electing a person, who does not meet the established requirements; 4) violates one's right to information on public activity of persons authorized to perform functions of state or local government, in particular on its objectivity, reliability, completeness and accuracy; 5) causes incorrect assessment of the activities of the state or local government representatives; 6) reveals illegal and unethical behavior of such persons.

2. The need to ensure the fulfillment of the obligation to declare persons authorized to perform functions of state or local government. The threat of criminal punishment encourages relevant entities to declare their income and expenses, to explain the origin of their assets in the declaration.

3. The need to create preconditions for proving illicit enrichment. Without a rule on criminal liability for declaration, establishing the fact of illicit enrichment becomes questionable.

4. The need to ensure transparency in the activities of persons authorized to perform functions of state or local self-government. Relevant provisions provide for an opportunity to objectively assess their work, as well as in certain cases to identify possible elements of illegal acts.

5. Availability of potential in the context of corruption offenses prevention. Criminal liability for declaring inaccurate information hinders the unimpeded use of illegally acquired assets and their unhindered concealment. Discussed provision encourages the offender to take action in order to legalize illegal assets, since he is not able to spend them at will.

6. The need to fulfill obligations enshrined in the Constitution of Ukraine. According to Art. 67 of the Constitution of Ukraine (1996), everyone is obliged to pay taxes and fees in the manner and amounts 
prescribed by law. All citizens annually submit declarations of their property and income for the previous year to the tax offices at the place of residence and in the manner prescribed by law.

7. Ukraine's legal obligations before the international community to prevent and combat corruption offenses.

Third, experience of other countries testifies to the expediency of the existence of criminal liability for intentional non-submission of declarations and for filing knowingly inaccurate information.

Thus, it is no coincidence that the CCU Judge V. Lemak has stressed out: "I do not agree in principle with the denial of the idea of criminalizing the relevant act, as evidenced by the experience of the entire civilized world" (Lemak, 2020: 29). As S. Holovaty correctly noted, introduction of effective deterrent sanctions for providing knowingly inaccurate information in declarations is an international standard and an important element of the general system of reporting assets by public figures. For example, the OECD Anti-Corruption Network for Eastern Europe and Central Asia has repeatedly recommended that Ukraine ensures the effectiveness of sanctions for failure to provide or for providing false information in declarations (Holovaty, 2020).

Indeed, liability for intentional failure to file a declaration and file knowingly inaccurate information meets international standards for preventing and combating corruption. In accordance with Part 5 of Art. 8 of the United Nations Convention against Corruption (2003), each State Party shall endeavor, where appropriate and in accordance with the fundamental principles of its domestic law, to establish measures and systems requiring public officials to make declarations to appropriate authorities regarding, inter alia, their outside activities, employment, investments, assets and substantial gifts or benefits from which a conflict of interest may result with respect to their functions as public officials.

In this regard, the world employs the following models of liability for such acts: 1) criminal liability (recognition of such acts as crimes or misdemeanors); 2) administrative liability (recognition of such acts as administrative offenses); 3) disciplinary liability (recognition of such acts as disciplinary offenses); 4) mixed liability (recognition of such acts as crimes, as well as administrative or disciplinary infractions).

Criminal law of foreign nations addresses issues of filing inaccurate information and intentional failure to submit a declaration differently: in some countries criminal liability is provided only for filing inaccurate information (Bulgaria, Italy, Latvia, Liechtenstein, Macedonia, Moldova, Croatia), while in others - for declaring inaccurate information and intentional failure to submit declaration (Albania, Georgia, Czech Republic). 
Analysis of the sanctions provided for in these articles demonstrates that they are alternative in nature and include penalties in the form of fines, community service, deprivation of the right to hold a certain position or engage in certain activities, imprisonment for a certain period. This proves the fact that imprisonment not only in Ukraine but also in other countries is recognized as an adequate legal instrument designed to counteract intentional failure to submit a declaration or to declare knowingly inaccurate information.

The second argument of unconstitutionality is based on a violation of the rule of law principle, in particular of such its elements as legal certainty and predictability of law.

Having investigated elements of the crime under Art. 366-1 of the Criminal Code of Ukraine (2001), the CCU concluded that the use of legal structures, which do not have a clear list of laws, makes it impossible to unambiguously define the range of subjects of crime, and reference rules make it impossible to establish the range of their addressees. As a result, persons, who cannot be subjected to the declaratory requirements and therefore knowingly failed to do so, may be held liable for intentional failure to file a declaration. This is not consistent with the concept of the lawful state and the principle of the rule of law, enshrined in Part 1 of Art. 8 of the Constitution of Ukraine (1996), in particular with such elements as legal certainty and predictability of law (Decision of the CCU, 2020).

We do not agree with such approach. Firstly, grounds for criminal liability for declaring inaccurate information have appeared as a result of the adoption of the Law of Ukraine "On Prevention of Corruption" (2014), which has provided, in particular, for amendments to Article 366-1 of the Criminal Code of Ukraine (2001). Since then, the practice of declaring income, expenses and liabilities has developed. Therefore, in 2020 no doubt exists on the range of declaration subjects and, accordingly, the perpetrators of crime under Art. 366-1 of the Criminal Code of Ukraine (2001).

Secondly, the statement of the CCU that the lack of a clear list of laws makes it impossible to unambiguously define the range of subjects of crime is not true. In the note to Art. 366-1 of the Criminal Code of Ukraine (2001) offenders are clearly defined: the persons responsible for the declaration are persons who, in accordance with Part 1 and 2 of Art. 45 of the Law of Ukraine "On Prevention of Corruption" (2014) are obliged to submit a declaration of a person authorized to perform functions of state or local government.

Instead, two categories of persons are mentioned in parts 1 and 2 of Art. 45 of the Law of Ukraine "On Prevention of Corruption" (2014): 1) persons referred to in paragraph 1 , subparagraphs "a" and "c" of paragraph 2 of the first part of Article 3 of this Law, who are required to submit a 
declaration by April 1 for the last year; 2) persons referred to in paragraph 1, subparagraphs "a" and "c" of paragraph 2 of the first part of Article 3 of this Law, who terminate activities related to the performance of state or local government functions and file a declaration for a period not previously covered by submitted declarations.

At the same time, reference to paragraph 1, subparagraphs "a" and "c" of paragraph 2 of Part 1 of Art. 3 of this Law allows to clearly identify such persons. Among them are, for example, members of the Parliament of Ukraine, deputies of the Supreme Council of the Autonomous Republic of Crimea, deputies of local councils, village, city mayors, civil servants, local government officials, etc.

Thirdly, even assuming that there are doubts about the classification of certain categories of persons as declarants, they can seek clarification from the National Agency for the Prevention of Corruption. In addition, the law provides for appropriate mechanisms for notifying each person on the need to file a declaration, which also eliminates their reference to the ignorance of the obligation to file a declaration.

Other violations committed by the judges are also noteworthy:

1. The CCU also ruled on the provisions of the legislation on corruption prevention, which have not been challenged in the constitutional petition.

2. During the decision-making process, three CCU judges acted under the conflict of interest, as the procedure of bringing them to administrative and criminal responsibility has been underway. At the same time, withdrawal (self-withdrawal) has not been used.

3. Judges of the Constitutional Court of Ukraine could postpone expiration of certain provisions of the Law and the Code, which have been declared unconstitutional. However, they did not provide the Verkhovna Rada of Ukraine (the national Parliament) with enough time to rectify the situation with the prohibition on declaring inaccurate information. This can be explained, in particular, by the fact that the provision does not have defects, due to which it can be declared unconstitutional.

Given the unfoundedness of the relevant decision of the Constitutional Court of Ukraine, Verkhovna Rada of Ukraine restored the grounds for criminal liability for these acts, which are very similar to those declared unconstitutional. This is no surprise given that foreign experience reveals that criminal law recognizes mostly two acts: failure to file a declaration and filing inaccurate information.

The Criminal Code of Ukraine (2001) has been supplemented by Art. 366-2, which establishes liability for intentional entry by the subject of 
declaration of knowingly unreliable information in the declaration of a person, who is authorized to perform functions of state or local government, provided by the Law of Ukraine "On Prevention of Corruption" (2014), if such information differs from the correct one in the amount of 500 to 4000 subsistence minimums for able-bodied persons and Art. 366-3, which establishes liability for intentional failure of the subject to declare the declaration of a person authorized to perform functions of state or local government, provided by the Law of Ukraine "On Prevention of Corruption" (2014).

Major differences of the new criminal law instruments include: 1) establishing liability for these actions in various articles of the Criminal Code of Ukraine (2001); 2) increasing the threshold of criminal liability for declaring inaccurate information (previously, liability occurred, if the information in the declaration differed from the correct one by the value of more than 250 subsistence minimums for able-to-work persons; in the new law it starts from 500 subsistence minimums for able-to-work persons); 3) changing sanctions applied for the offense (imprisonment for up to 2 years has been excluded, the amount of the fine has been increased and restraint of liberty for up to 2 years has been added).

\section{Conclusion}

Decision of the CCU on the recognition of Art. 366-1 of the Criminal Code of Ukraine (2001) as the one, which does not comply with the Constitution of Ukraine (1996), is insufficiently substantiated. Its main shortcomings include: 1) criminalization of a socially dangerous act is a matter for the legislator to decide, not for the CCU; 2) the CCU has not cited or refuted any argument about the social harmfulness of this act; 3) relevant foreign experience testifies to the expediency of criminal liability for intentional non-submission of declarations and declaration of knowingly inaccurate information; 4) the principle of rule of law has not been violated in Art. 366-1 of the Criminal Code of Ukraine (2001).

Other violations committed by CCU judges are evidenced by the following circumstances: 1) relevant decision also concerned provisions of the legislation on the prevention of corruption, which have not been challenged in the constitutional petition; 2) during its adoption, three CCU judges acted within a conflict of interest; 3) CCU judges did not postpone expiration of certain provisions of the Law "On Prevention of Corruption" (2014) and the Criminal Code (2001).

Circumstances, which determine the need to criminalize intentional failure to file a declaration and declare inaccurate information have been formulated: 1) social harmfulness of such acts; 2) the need to ensure 
compliance with the obligation to declare; 3 ) the need to create preconditions for proving illegal enrichment; 4) the need to ensure transparency in the activities of persons authorized to perform functions of state or local government, objective assessment of their work; 5) availability of potential in the context of corruption offenses prevention; 6) the need to fulfill obligations enshrined in the Constitution of Ukraine; 7) international legal obligations of Ukraine to prevent and combat corruption-related offenses.

Given the absence of appropriate legal rationale for the relevant decision of the CCU, the national Parliament has restored grounds for criminal liability for such acts, which are similar to those declared as unconstitutional and also comply with the international standards.

\section{Bibliographic References}

CHERNIAVSKYI, Serhiy; VOZNIUK, Andriy. 2019. "Foreign experience of legal counteraction to illicit enrichment" In: Law Magazine of the National Academy of Internal Affairs. Vol. 17, No. 1, pp. 79-89.

CONSTITUTION OF UKRAINE. 1996. Law of June 28, 1996, No. 254k/96-VR. Available online. In: https://zakon.rada.gov.ua/laws/ show/254\%Do\%BA/96-\%Do\%B2\%D1\%80. Consultation date: 22/12/2020.

CONSTITUTIONAL COURT OF UKRAINE. 2020. Case № 1-24/2020 (393/20). Decision in the case on constitutional petition of 47 people's deputies of Ukraine on compliance with the Constitution of Ukraine (constitutionality) of certain provisions of the Law of Ukraine "On Prevention of Corruption", the Criminal Code of Ukraine of October 27, 2020, no 13-r/2020. Available online. In: http://ccu.gov.ua/ dokument/13-r2020. Consultation date: 22/12/2020.

CRIMINAL CODE OF UKRAINE. 2001. Law of April 5, 2001. No. 2341-III. Available online. In: https://zakon.rada.gov.ua/laws/show/234114\#Text. Consultation date: 22/12/2020.

DUDOROV, Oleksandr; KOLOMOIETS, Tetyana; KUSHNIR, Serhiy, MAKARENKOV Oleksiy. 2019. General theoretical, administrative and criminal law bases of conceptualization of anti-corruption reform in Ukraine: collective monograph. Zaporizhzhya. Ukraine.

HOLOVATY, Serhiy. 2020. Dissenting opinion of the judge of the Constitutional Court of Ukraine on the compliance of the Constitution of Ukraine (constitutionality) with certain provisions of the Law of Ukraine "On Prevention of Corruption", the Criminal Code of Ukraine. Available 
Andrii Vozniuk, Dmitriy Kamensky, Olexandr Dudorov, Roman Movchan y Andriy Andrushko

144 Unconstitutionality of criminal liability for filing inaccurate information in Ukraine: critical legal analyses

online. In: http://www.ccu.gov.ua/dokument/13-r2020. Consultation date: $22 / 12 / 2020$.

KAMENSKY, Dmitriy; DUDOROV, Oleksandr; MOVCHAN, Roman; VOZNYUK, Andriy; MAKARENKO, Tamara. 2020. "Insider trading in the global economic environment: elements of criminal liability" In: International Journal of Management. Vol. 11, No. 12, pp. 1679-1688.

KOLISNYK, Viktor. 2020. Separate opinion of the judge of the Constitutional Court of Ukraine on the compliance of the Constitution of Ukraine (constitutionality) with certain provisions of the Law of Ukraine "On Prevention of Corruption: the Criminal Code of Ukraine. Available online. In: http://www.ccu.gov.ua/dokument/13-r2020. Consultation date: $22 / 12 / 2020$.

LAW OF UKRAINE. 2014. Law No. 1700-VII. On Prevention of Corruption. October 14. Available online. In: https://zakon.rada. gov.ua/laws/show/1700-18\#Text. Consultation date: 22/12/2020.

LEMAK, Vasyl. 2020. Dissenting opinion by the judge of the Constitutional Court of Ukraine on the compliance of the Constitution of Ukraine (constitutionality) with certain provisions of the Law of Ukraine "On Prevention of Corruption", the Criminal Code of Ukraine. Available online. In: http://www.ccu.gov.ua/dokument/13-r2020. Consultation date: $22 / 12 / 2020$.

NATHANSON, Stephen. 2013. "Why good government matters" In: Crime, Law and Social Change. Vol. 60, No. 1, pp. 107-114.

NATIONAL AGENCY OF CORRUPTION PREVENTION. 2020. On the letter of the Presidents of GRECO and the Venice commission to the chairman of the Verkhovna Rada regarding the constitutional crisis in Ukraine. Available online. In: https://nazk.gov.ua/uk/novyny/shhodo-lystaprezydentiv-greco-ta-venetsijskoyi-komisiyi-do-golovy-verhovnoyirady-stosovno-konstytutsijnoyi-kryzy-v-ukrayini. Consultation date: $22 / 12 / 2020$.

PERVOMAISKY, Oleh. 2020. Dissenting opinion by the judge of the Constitutional Court of Ukraine on the compliance of the Constitution of Ukraine (constitutionality) with certain provisions of the Law of Ukraine "On Prevention of Corruption", the Criminal Code of Ukraine. Available online. In: http://www.ccu.gov.ua/dokument/13-r2020. Consultation date: $22 / 12 / 2020$. 
PROSECUTORGENERALOFUKRAINE. 2016-2020. Statistical reporting ofthe Office of the Prosecutor General of Ukraine. Available online. In: https:// old.gp.gov.ua/ua/stst2011.html?dir_id=114140\&libid=100820\#. Consultation date: 22/12/2020.

UNITED NATIONS. 2003. Convention Against Corruption. Available online. In: https://www.unodc.org/documents/brussels/UN_Convention_ Against_Corruption.pdf. Consultation date: 22/12/2020.

VOZNIUK, Andriy; DUDOROV, Oleksandr; MOVCHAN, Roman; TYTKO, Anna. 2020. "Implementation of UN and EU recommendations on criminalization of organized crimes" In: Amazonia Investiga. Vol. 9, No. 28, pp. 234-240.

VOZNYUK, Andriy. 2019. "Psychological theories to explain corruption" In: Legal psychology. Vol. 25, No. 2, pp. 7-15. 
Vol. 39 N $^{\circ} 69$

Esta revista fue editada en formato digital y publicada en julio de 2021, por el Fondo Editorial Serbiluz, Universidad del Zulia. Maracaibo-Venezuela 